\title{
The need for collaboration in early communication intervention: Whom do parents consult regarding the prevention of communication disorders?
}

\author{
E. Popich, B. Louw and I. Eloff*
}

Elsa Popich, D Phil, Department of Communication Pathology, University of Pretoria.

Postal address:

\author{
Dept of Communication Pathology \\ University of Pretoria \\ Lynwood Road \\ Brooklyn \\ Pretoria \\ 0002 \\ South Africa
}

E-mail: elsapopich@ananzi.co.za

Telephone: +61 (0)3 55611237

Fax: +27 (0)12460 8016

Brenda Louw, Prof., Head: Department of Communication Pathology, University of Pretoria.

Postal address: $\quad$ Dept of Communication Pathology

University of Pretoria

Lynwood Road

Brooklyn

Pretoria

0002

South Africa

E-mail: brenda.louw@up.ac.za

Telephone: (012) 4202491

Fax: (012) 4203517

* Corresponding author:

Irma Eloff, Prof., Head: Department of Educational Psychology, University of Pretoria.

Postal address:

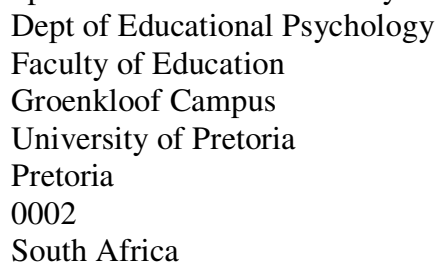

E-mail: irma.eloff@up.ac.za

Telephone: (012) 4205503

Fax: (012) 4205511 


\title{
The need for collaboration in early communication intervention: Whom do parents consult regarding the prevention of communication disorders?
}

\begin{abstract}
The purpose of this article is to: (1) report findings regarding the needs of parents for information on communication development, (2) review the range of professionals whom parents frequently consult regarding communication development, (3) discuss the frequency with which professionals provide information on communication development to parents and (4) call early interventionists to action regarding involvement in transdisciplinary teams for the prevention of communication disorders. Two parallel surveys, one with parents $(n=184)$ and one with professionals $(n=83)$ as well as focus group discussions were utilised to reflect the perspectives of a variety of early intervention professionals and parents. Results indicated that parents desire more information on infant communication development and regularly consult a range of professionals in order to obtain information on the stimulation of communication skills and the prevention of early communication disorders. This has implications regarding the need for access to consistent, accurate information and the involvement of all early intervention professionals in the prevention of communication disorders.
\end{abstract}

Key words: prevention; communication disorders; transdisciplinary teams; early intervention professionals; communication development 


\section{INTRODUCTION}

There is a growing awareness of the importance of focusing on communicative wellness, the promotion of normal development and the prevention of communication disorders (Werner, 2000; Gerber, 1998; ASHA, 1991). Focusing on the prevention of communication disorders is an international trend which reflects a move from tertiary prevention towards secondary and ultimately primary prevention (Gerber, 1998).

According to ASHA (1991) the prevention of communication disorders is one of the primary roles of speech-language pathologists and encompasses not only the application of prevention strategies but also the need for research on the prevention of communication disorders. Prevention efforts have been found to be effective in reducing the prevalence of communication disorders such as hearing loss which are caused by pre-natal rubella exposure, and prevention is also more cost-effective when compared to the alternative costs of rehabilitation (Rossetti, 2001; Gerber, 1998; Hussey, Lasser \& Reekie, 1995).

Yet, in spite of the call for speech-language pathologists to become involved in preventative efforts and the track record of implemented programmes, this role has frequently been neglected or regarded as a secondary function by many speechlanguage pathologists in South Africa (Kritzinger, 2000; Hugo, 1998). Communities in South Africa face a variety of different challenges including high rates of poverty and a lack of resources in underdeveloped areas (Ebersöhn \& Eloff, 2002). Children in South Africa are at an increased risk for the development of communication disorders due to a higher prevalence of risk factors such as low birth weight, Down Syndrome, cleft lip and palate, cerebral palsy, fetal alcohol syndrome, HIV and AIDS, multilingualism and significant bilateral sensori-neural hearing loss (Ainsworth \& Filmer, 2002; Kritzinger, 2000; Pickering et al., 1998). These risk factors increase the need for the prevention of communication disorders and the provision of adequate early intervention services.

In South Africa many speech-language pathologists in clinical practice have traditionally focused on the provision of one-to-one rehabilitative therapy while 
neglecting roles such as prevention, education and early identification (Hugo, 1998). This uneven distribution of service provision may have been the result of limited professional training regarding prevention services as well as an emphasis on secondary and tertiary prevention efforts (Gerber, 1998). However, recent trends in service provision indicate a greater emphasis in South Africa regarding the roles of speech-language pathologists in aspects such as prevention, education and consultation (Hugo, 1998). Inherent in this trend is not only the need to identify and prevent the occurrence of diseases which are linked to communication disorders, but also the need for an increasing focus on early intervention and the promotion of wellness within communities (Gerber, 1998; Billeaud, 1998).

In light of the recognised importance of the early years and in order to promote optimal development and wellness, the importance of communication development in infants and young children cannot be ignored. Communication development has a reciprocal influence on many other areas of infant development (Owens, 2001) and is often a source of concern to parents (Rossetti, 2001). Concerned parents may, however, not always consult a speech-language pathologist regarding their child's communication development, but may consult one of many different professionals with whom they come into contact (Rossetti, 2001). Besides the fact that parents may choose to seek advice from another source, in countries such as South Africa there may not be a speech-language pathologist available to every parent or parents may choose not to consult a professional at all.

There is, however, a shortage of qualified speech-language pathologists in South Africa, hindering the provision of the necessary early intervention and prevention services to families. It was correctly predicted in the nineties that there would be a shortage of approximately 5000 speech-language pathologists in South Africa by the year 2000 (Uys, 1993). The effective provision of early intervention and prevention services in countries such as South Africa therefore depends on the close co-operation between speech-language pathologists and other early intervention professionals (Fair \& Louw, 1999).

Professionals benefit from transdisciplinary teamwork where they retain their disciplinary expertise while benefiting from the shared knowledge and experience of 
other disciplines (Rossetti, 2001). Early childhood professionals who work with infants and their parents should have access to accurate information and guidelines on the stimulation of infant communication skills. Professionals who are involved in service provision to families with infants should maintain a spirit of collaboration in order to best promote the development of communication skills in infants (Rossetti, 2001). Parents have an important role to play in the promotion of optimal development, the early identification of delays and disorders as well as the prevention of communication disorders (Rossetti, 2001).

Prevention has been highlighted above as an important role for all speech-language pathologists in South Africa. However, the question is raised whether this role is primarily the responsibility of speech-language pathologists or whether it is a shared responsibility of all early interventionists? This gives rise to the question of which professionals should potentially be involved in the prevention of communication disorders?

This article views current trends in the provision of information to parents on communication development, by early intervention professionals within a South African community, and considers the need for early interventionists to become involved in transdisciplinary teams for the prevention of communication disorders in order to meet the needs of families and ensure the provision of consistent, accurate information.

\section{METHODOLOGY}

\section{Research aim}

The aim of the research was to determine whether there is a need for information on the prevention of communication disorders to be provided to parents and, if so, to consider which professionals could collaborate their efforts in order to achieve this aim, making information available to all families. This study proposes to explore the current trends for information provision on communication development and the prevention of communication disorders within a South African community. 


\section{Research design}

An explorative, descriptive survey design was employed utilizing questionnaires and focus group discussions providing both quantitative and qualitative information. The use of a descriptive survey allowed the researchers to determine the attitudes of a large number of participants (Leedy \& Ormrod, 2001). Surveys are viewed as ideal tools for determining the attitudes of a community (Stein \& Cutler, 1996). Focus group discussions were used in order to compliment the survey by obtaining a broader, richer perspective on the needs and opinions of parents from the target community (Bloor, Frankland, Thomas \& Robson, 2001).

\section{Population and sampling}

This study targeted both parents of infants as well as professionals within a specific South African community in order to gain a balanced perspective on perceptions regarding the need for information on communication development and the actual provision of such information. The community which was selected can be described as falling within the developed range of the continuum of South African communities. The participants that were included in this research are described in Table I.

\section{Insert Table I here}

\section{Description of Participants}

A total of 184 parents of infants younger than 18 months from the community completed questionnaires in the survey and are described in table II.

\section{Insert Table II here}

Two of the groups of parents attending parent-infant workshops were invited to participate in further discussions upon completion of the questionnaires and are described in Table III.

\section{Insert Table III here}

When comparing the biographical information in Table III with the information on the survey participants, it appears that the participants who took part in the focus group discussions were representative of the survey group. This is important as it reflects on 
the validity of the information that was obtained through the focus group discussions (Carey, 1994).

All English-speaking professionals with relevant qualifications (educational psychologists, nurses doing pre-natal education, parent-infant workshop leaders, social workers, speech-language pathologists and occupational therapists) who were involved in early intervention by working with infants or pre-school children within the boundaries of the selected community were invited to participate in the research. A total of 83 professionals from the community completed questionnaires in the survey. The different professionals who participated in this study are displayed in Figure 1.

\section{Insert Figure 1 here}

According to Figure 1 the professional participants were distributed fairly evenly over six different professions with a slightly larger proportion of speech-language pathologists. The data regarding parents' informational needs therefore reflects the knowledge and experience of a variety of different professionals. Since concerned parents may choose to consult one of many different professionals regarding their child's communication development (Rossetti, 2001) it was therefore crucial to include the opinions of as many different relevant professionals as possible. These professionals are described in more detail in Table IV.

\section{Insert Table IV here}

\section{Data collection}

Data collection included surveys by a compiled questionnaire and focus group discussions.

Procedures for the surveys

Two questionnaires were compiled (one directed at parents and another at professionals) with the aim of determining the need for a tool ${ }^{1}$ for information on the stimulation of communication in infants, the format in which parents preferred

\footnotetext{
${ }^{1}$ The use of a tool was indicated because the study also explored the format in which parents would prefer information on communication development in infants to be presented.
} 
information to be presented and the desired content for a tool that would provide the information. Participants were presented with an informed consent form which provided information on the purpose of the research, the procedures followed, confidentiality and consent (Stein \& Cutler, 1996). Both questionnaires are available, on request, from the corresponding author.

Procedures for the focus group discussions

Pre-existing social groups who were familiar and comfortable with each other were used and the venue for the discussions were the same as where the groups usually gathered making it a familiar and convenient setting for all the participants (Bloor et al., 2001). An external rater observed the focus group discussions and questions from the survey were used to prompt discussion. The discussions were taped on audio and video cassettes and transcribed verbatim according to transcription guidelines provided by Bloor, et al. (2001).

\section{RESULTS}

Firstly, parental perceptions of their own knowledge regarding infant communication skills were determined. The results are displayed in Figure 2.

\section{Insert Figure 2 here}

According to Figure 2 the majority of the participants felt that they were not sufficiently informed regarding infant communication development in order to help prevent the development of communication problems in their infants.

Furthermore, the survey also probed whether participants felt that information on infant communication development should be readily available to them. The results are displayed in Figure 3.

\section{Insert Figure 3 here}

According to Figure $387,5 \%$ of the participants felt that information on infant communication development should definitely be readily available to parents. This response becomes even more convincing when viewed in the light of the previous 
result, namely that participants did not feel sufficiently informed regarding infant communication development. Clearly participants desired more information to be made available to them.

The results of the two focus group discussions indicated that parent participants of these groups expressed a similar need for information on the stimulation of communication skills in infants in order to feel more empowered and less stressed about their children's development. Furthermore, both focus groups desired knowledge of normal communication development. These results confirm the findings of the survey, namely that parent participants desired more information on infant communication.

Professional's perceptions of parents' levels of knowledge regarding infant communication skills were also explored. The results are displayed in Figure 4.

\section{Insert Figure 4 here}

According to Figure 4 the majority of professional participants felt that parents are not sufficiently informed in order to prevent the development of communication problems in infants.

Furthermore the survey probed professionals feelings regarding making information on infant communication development readily available to parents. The results are displayed in Figure 5.

\section{Insert Figure 5 here}

Figure 5 indicates that $98,8 \%$ of the professional participants felt that information should definitely be readily available to parents, which coincides with the previous finding, namely that the majority of professionals felt that parents are definitely not sufficiently informed.

The survey also gathered information on how often professionals provide information to parents as well as how often professionals are requested by parents to provide 
information on infant communication development. The results are displayed in Figures 6 and 7.

\section{Insert Figures 6 and 7 here}

According to Figure 6 the professional participants felt that they provided parents with information on infant communication development on a regular basis. A total of $82 \%$ of the different professionals involved in this study stated that they provide parents with information on communication development on a weekly (47\%) or monthly (35\%) basis. A further $18 \%$ provide parents with information on communication development every few months. It is important to note that all of the professionals involved in this study provided parents with information on communication development.

Figure 7 illustrates that the professional participants also stated that parents request information on infant communication development on a regular basis. The majority of parents frequently request information on communication development. It appears to be the opinion of the professional participants that only $2 \%$ of all parents they see request information once a year or never.

It is clear, therefore, that a desire for parents to be more informed regarding infant communication development and the prevention of early communication disorders was expressed by parents, both in the survey as well as in the focus group discussions. This view is supported by the results of the questionnaire aimed at professionals.

\section{DISCUSSION}

The results indicated that $84 \%$ of parents' had the perception that their knowledge of infant communication development was insufficient. A need was, therefore, identified for additional information on communication development to be provided to parents in the specific community in order to empower these parents with the knowledge and ability to prevent communication disorders. Due to the increased risk for developing communication disorders and a shortage of qualified professionals in countries such as South Africa there is a great need for parents to become more central figures in the decision-making process regarding their infant's development. In order to be involved 
parents need to have access to all the applicable information so that they are empowered to make informed, accurate decisions (Rossetti, 2001).

The results further indicated that $87 \%$ of parent participants felt strongly that information should be made readily available to parents. Parents from all communities aim to stimulate optimal development in their children (Garcia Coll \& Magnuson, 2000) and many communication disorders may be prevented by providing parents with the necessary information (Hugo \& Pottas, 1997). It is therefore important that information be made available to parents to enable them to fulfil their role as central figures in facilitating optimal development in their infant. Professionals should strive to provide parents with the information they need and desire. Professionals should form partnerships with families and communities in order to empower them with the information they need to promote optimal development (Mc Conkey, 2002).

From the results of the second survey, which was aimed at professional participants, it is clear that professionals perceive parents as under informed and that information needs to be made available to parents in order to empower them to be more involved in the stimulation of communication skills. A comparison between the results indicates that both parent and professional participants felt strongly that information should be made readily available to parents.

The finding that all the professionals who participated in the survey are involved in providing information on communication development to parents of infants and young children is important when one considers that speech-language pathologists, occupational therapists, educational psychologists, nurses, parent-infant workshop leaders as well as social workers were targeted in the research. Some of these professionals (such as the nurses, parent-infant workshop leaders and social workers) provide services primarily to normally developing children whilst other professionals (such as the speech-language pathologists, occupational therapists, educational psychologists) tend to serve young children with disorders and disabilities as well. The sampling of professionals was fairly broad in this study, yet the indications are that they all appeared to be involved in providing parents with information on communication development. 
The findings, which indicated that a large majority of professional participants are frequently called upon to provide parents with information, therefore imply that both parents of children with disorders, as well as parents of normally developing children, desired more information on infant communication development. It is apparent that parents are aware of their need for more information and desire to be involved in the promotion of optimal communication development and the prevention of communication disorders.

It is clear that all of the before-mentioned professionals are involved to some degree in providing parents in the community with information on communication development. These different professionals could, therefore, be viewed as part of an informal transdisciplinary team working on infant communication development in this specific community.

This has important implications for the community as not all the professionals would have had access to the same information and training in the area of infant communication development. It is, however, critical that parents are provided with consistent, accurate information in order to decrease confusion for families. The different professionals within a transdisciplinary team should have access to the necessary information and should work towards common goals (Rossetti, 2001). It is crucial, therefore, that speech-language therapists develop their role in order to become more involved in the education of other professionals on communication development and the prevention of communication disorders. As a result of increases in knowledge, a better understanding of the factors influencing communication development will evolve and members of the teams will be better equipped to participate in the prevention of communication disorders (Briggs, 1997). All professionals who participate in a transdisciplinary team would need to contribute training and experience which is typical of their discipline but will also move across traditional boundaries, releasing certain roles and responsibilities to other professionals (Briggs, 1997). This will empower the members to become more effective in promoting optimal communication development and preventing communication disorders. 


\section{A CALL FOR ACTION}

In the past early intervention services in South Africa tended to be fragmented but current trends reflect a move towards the development of transdisciplinary teams (Rossetti, 2001; Moodley, Louw and Hugo, 2000). Currently, a need exists for consistent and accurate information on communication development to be provided to parents (Rossetti, 2001). When all professionals involved in providing information to a family have access to the same information, the information provided to the family is more consistent, which is in line with current trends in family-centred practice (Guralnick, 1997). When professionals do not work together to provide consistent information it may cause stress to the family (Guralnick, 1997). The results of this study indicate that professionals from various fields are probably already involved in providing parents with information on communication development. However, without the formation of more formalised transdisciplinary teams within communities, the information provided to families may remain fragmented and even confusing, which may result in an increase in anxiety within families.

The development of communication skills influence, and are influenced, by other areas of development such as cognitive, socio-emotional and physical development (Klass, 1999; Kritzinger, Louw \& Hugo, 1995). There is a reciprocal influence in the development of different skill areas and consequently it is important that all members of the transdisciplinary team are involved in the prevention of early communication disorders.

Just as research has proposed a transdisciplinary conceptual framework for the early identification of communication disorders (Kritzinger, Louw and Rossetti, 2001) a possible solution for the prevention of communication disorders in South Africa may also follow a similar approach. The use of transdisciplinary teams would allow for the participation of a number of different professionals in the prevention of communication disorders. Moodley (1999) has indicated that this may be achieved in South Africa through the implementation of transdisciplinary training programmes which focus on training professionals from other disciplines in the identification and referral of children who are at risk for communication disorders or delays. 
These teams should be characterised by the following: professionals from different disciplines would participate in the team, actions would be based on collaboration and consensus decision making, the needs of families would be central to the decisions made and the provision of services would be co-ordinated (Kritzinger et al., 2001; Fair \& Louw, 1999). Due to the synergistic relationship between different areas of skill development all the team members will have a vested interest in becoming involved in preventative programmes. Through the provision of skill development and the transferral of knowledge speech-language therapists can release this role and encourage the joint participation of other professionals (Briggs, 1997).

Members of transdisciplinary teams for the prevention of communication disorders would need to understand the factors that place individuals at risk for communication disorders (ASHA, 1991). Effective teamwork with other members of the transdisciplinary team is an important component of developing an understanding of these factors. Teamwork would promote the exchange of information regarding risk factors which may impede the infant's ability to interact with the environment (Rossetti, 2001).

Furthermore, an understanding of the conditions that promote the development of optimal communication abilities is also necessary as promoting optimal communication development is viewed as a proactive form of primary prevention (Gerber, 1998; ASHA, 1991). In contrast with other primary prevention actions which focus on the prevention of negative risk factors or disease, a focus on stimulating the development of optimal communication skills in infants implies a focus on strengths. The effectiveness of promoting optimal development would rely on information exchange and the development of shared meaning between team members.

Another important function of a transdisciplinary prevention team in South Africa would be the early identification of risks and disorders, as the implementation of effective communication-related prevention measures depends upon identifying the factors which increase the risk for communication delays. It would be important to plan and execute identification programmes (Hugo, 2003). The effectiveness of ECI service delivery depends on the early identification of children who are at risk for communication disorders (Kritzinger, 2000). Professionals from other disciplines may 
require information and training on the early identification of children who are at-risk as they may not have had the specific training necessary. Speech-language therapists have a responsibility, therefore, to share their discipline-specific knowledge and skill and become involved in the education of other professionals on communication development and the early identification of communication disorders.

The need for all members of the transdisciplinary prevention teams to have access to knowledge on risk factors, the promotion of optimal communication development as well as the early identification of risks and disorders implies that speech-language pathologists will be required to provide adult education, including imparting knowledge and skill training. The prevention of communication and related disorders requires speech-language pathologists to contribute towards the dissemination of information and participate in the planning and execution of prevention programmes (Hugo, 2003). Speech-language pathologists need also be "brokers of information" (Rossetti, 2001), no longer guarding their specialised knowledge and skills (Uys \& Hugo, 1997). As a result of increases in knowledge, a better understanding of the factors influencing communication development will evolve (Briggs, 1997). As a result the individual members of the transdisciplinary teams will be better equipped to participate in the prevention of communication disorders in South Africa (Briggs, 1997). This will empower the members to become more active in team efforts to develop prevention programmes. In order to establish effective teams, which address the desires of families, there is a need for the collective empowerment of both parents and professionals (Shonkoff \& Meisels, 2000).

The proposed outcome of transdisciplinary teams in the prevention of early communication disorders is the promotion of optimal communication development and the prevention of communication disorders within communities. This can be achieved by the development of shared meaning between professionals through transdisciplinary training. This implies that all of the professionals who are involved in the prevention of communication disorders will have access to the same information and will have reached a consensus as to the objectives of the prevention programme, therefore reducing the anxiety and confusion for families. Communities as a whole will benefit from accurate, complete and consistent information being provided to them. This can be done most effectively through the involvement of a 
range of different professionals (Alant \& Mophoso, 2003; Moodley et al., 2000; Fair \& Louw, 1999).

This study has highlighted that any professional who comes in contact with parents of infants or young children in South Africa is likely to be approached with questions on communication development. The provision of information and the prevention of communication disorders can, consequently, not be the sole responsibility of the speech-language pathologist. All early interventionists who come into contact with parents of infants and young children are, therefore, called upon to form part of the professional network which aims to assist in promoting optimal development and wellness and the prevention of communication disorders. But, in order to make such preventative actions successful in South Africa speech-language pathologists would have an important role to play as they would need to be actively involved in training and sharing discipline-specific knowledge with other professionals.

Although this research, which proposes a transdisciplinary approach to the prevention of communication disorders, has been conducted in South Africa, and is relevant to this context there are probably other contexts internationally which would make a similar model applicable. Other contexts where there are a continuum of communities, ranging from the developed to the developing or where there are a dearth of available services available to families, may also benefit from following a similar model. It is likely that within other communities parents may also be consulting a variety of different professionals in order to access information on communication development. Programmes for the prevention of communication disorders within these communities may, therefore, also benefit from involving these professionals in a transdisciplinary prevention role.

\section{References}

Alant, E. \& Mophosho, M. (2003) Early childhood intervention: Web-based training for transformation. South African Journal of Higher Education, vol. 17, no. 1, pp. 185-199.

Ainsworth, M. \& Filmer, D. (2002) Poverty, AIDS and children's schooling: a targeting dilemma, World Bank Policy Research Working Paper 2885. 
ASHA (1991) The prevention of communication disorders tutorial. ASHA, Supplement 6 to $33,9,15-39$.

Berg, B.L. (1998) Qualitative research methods for the social sciences. Allyn and Bacon, London.

Billeaud, F.P. (1998) Communication disorders in infants and toddlers. Second edition. Butterworth-Heinemann, Boston.

Bloor, M., Frankland, J., Thomas, M. \& Robson, K. (2001) Focus groups in social research. SAGE Publications, London.

Briggs, M.H. (1997) Building early intervention teams. Aspen Publishers, Inc. Maryland.

Carey, M.A. (1994) The group effect in focus groups: planning, implementing and interpreting focus group research. In Morse, J.M. (Ed.) Critical issues in Qualitative research methods. SAGE Publications, London.

Ebersöhn, L. \& Eloff, I. (2002) The black, white and grey of rainbow children's coping with HIV/AIDS. Perspectives in Education, vol. 20, no. 2, pp. 77-86.

Fair, L. \& Louw, B. (1999) Early communication intervention within a communitybased intervention model in South Africa. The South African Journal of Communication Disorders, vol. 46, no. 1, pp. 13-23.

Garcia Coll, C. \& Magnuson, K. (2000) Cultural differences as sources of developmental vulnerabilities and resources. In Shonkoff, J.P. \& Meisels, S.J. (Eds.) Handbook of early childhood intervention. Cambridge University Press, Cambridge.

Gerber, S.E. (1998) Etiology and prevention of communicative disorders. 2nd ed., Singular publishing group, London.

Guralnick, M.J. (1997) The effectiveness of early intervention. Paul H. Brookes, Baltimore.

Hugo, R. (2003) 'Report of the ad hoc committee on the development of competency profiles for the profession'. Unpublished report for the HPCSA, Pretoria.

Hugo, R. (1998) 'Communication pathology: the way in Africa'. The South African Journal of Communication Disorders, vol. 45, no. 1, pp. 3-10.

Hugo, R. \& Pottas, L. (1997) The primary prevention of communication disorders which result from chronic otitis media: a parent handout. Clinica: Applications in Clinical Practice of Communication Pathology, Monograph 2, 37-52. 
Hussey, G.D., Lasser, M.L. \& Reekie, W.D. (1995) The costs and benefits of a vaccination programme for Haemophilus influenzae type B disease. South African Medical Journal, 85, 20-25.

Kritzinger, A. (2000) Establishing a computer-based data system for early communication intervention in South Africa. Unpublished D Phil thesis, University of Pretoria, South Africa.

Kritzinger, A., Louw, B. \& Hugo, R. (1995) Communication skills of biologically atrisk neonates. The South African Journal of Communication Disorders, vol. 42, no. 1, pp 7-17.

Kritzinger, A., Louw, B. \& Rossetti, L.M. (2001) A transdisciplinary conceptual framework for the early identification of risks for communication disorders in young children. The South African Journal of Communication Disorders, 48, 1, $33-44$

Leedy, P.D., \& Ormrod, J.E. (2001) Practical research: Planning and design. 7th ed. Prentice-Hall, Inc, New Jersey.

Mc Conkey, R. (2002) Early childhood intervention: community based approaches. Seminar. The University of Pretoria, South Africa.

Moodley, L. (1999) An in-service training programme for community nurses in the identification of at-risk infants and toddlers. Unpublished masters thesis, University of Pretoria, South Africa.

Moodley, L., Louw, B. \& Hugo, S.R. (2000) Early identification of at-risk infants and toddlers: a transdisciplinary model of service delivery. The South African Journal of Communication Disorders, vol. 47, no. 1, pp. 25-39.

Owens, R.E. (2001) Language development: an introduction. 5th ed., Allyn and Bacon, London.

Popich, E., Louw, B. \& Eloff, I. (2004) Caregiver Education as a Prevention Strategy for Communication Disorders. Submitted for publication to Infants and Young Children.

Rossetti, L.M. (2001) Communication intervention: birth to three. 3rd ed., Singular: Thomson Learning, Canada.

Shonkoff, J.P. \& Meisels, S.J. (2000) Handbook of early childhood intervention. Cambridge University Press, Cambridge.

Stein, F. \& Cutler, S.K. (1996) Clinical research in applied health and special education. 3rd ed. Singular Publishing Group, Inc, London. 
Uys, I.C. (1993) 'Communication pathology: teaching for the future'. The South African Journal of Communication Disorders, vol. 40, no. 1, pp. 3-9.

Uys, I.C. \& Hugo, R. (1997) 'Speech-language pathology and audiology: transformation in teaching, research and service delivery'. Health SA Gesondheid, vol. 2, no. 2, pp. 23-29.

Werner, E.E. (2000) Protective factors and individual resilience. In Shonkoff, J.P. \& Meisels, S.J. (Eds.) Handbook of early childhood intervention. Cambridge University Press, Cambridge. 


\section{TABLES TO BE INSERTED}

\section{Table I: Research participants}

\begin{tabular}{|c|c|}
\hline Survey $(n=184$ parents +83 professionals: total $n=267)$ & Focus groups $(n=11)$ \\
\hline $\begin{array}{l}\text { - } 10 \text { randomly selected groups of parents attending parent-infant } \\
\text { workshops as well as } 10 \text { randomly selected groups of parents } \\
\text { attending pre-natal workshops }(\mathrm{n}=184) \text {. } \\
\text { - Speech-language pathologists, occupational therapists, educational } \\
\text { psychologists and social workers working with infants / pre-schoolers } \\
\text { or providing student training on related topics as well as nurses and } \\
\text { parent-infant workshop leaders involved in pre-and post-natal } \\
\text { education within the specific community }(\mathrm{n}=83) \text {. }\end{array}$ & $\begin{array}{l}2 \text { of the groups }(\mathrm{n}=5+ \\
\mathrm{n}=6) \text { of parents attending } \\
\text { parent-infant workshops } \\
\text { participated in further } \\
\text { discussions. }\end{array}$ \\
\hline
\end{tabular}

Table II: Parent participants who completed the survey $(n=184)$

\begin{tabular}{|c|c|}
\hline Criteria & Description \\
\hline Age & $\begin{array}{l}\text { The majority of the parent participants were in their late twenties and early thirties. } \\
\text { The ages of the participants may reflect the criteria which were used in selecting } \\
\text { participants, namely that all the parents that participated in the study had to either be } \\
\text { expecting an infant or they had to have a child that is younger than eighteen months. }\end{array}$ \\
\hline $\begin{array}{l}\text { Mothers } \\
\text { versus Fathers }\end{array}$ & $\begin{array}{l}\text { There were nearly twice as many mothers }(63,5 \%) \text { as fathers }(36 \%) \text { in this group and } \\
\text { only one stepfather participated in the study. This is explained by the fact that fathers } \\
\text { generally work (Louw et al., 1998) and are therefore unable to attend parent-infant } \\
\text { workshops. Almost all of the father participants were attending pre-natal classes with } \\
\text { their partners. These classes are presented at night and, therefore, allow for working } \\
\text { fathers to attend. }\end{array}$ \\
\hline $\begin{array}{l}\text { Family } \\
\text { structure }\end{array}$ & $\begin{array}{l}\text { The majority of participants }(91 \%) \text { were in a family structure where both biological } \\
\text { parents are present in the home. This result is not typical of international trends in } \\
\text { family structure as there is a climbing divorce rate in most countries (Lester, 1996). } \\
\text { The fact that } 91 \% \text { of the parent participants were part of a nuclear family may be } \\
\text { related to the fact that a large proportion were still young (late twenties and early } \\
\text { thirties). This age group is referred to as early adulthood and people within this group } \\
\text { are typically involved in forming intimate, lasting relationships (Louw et al., 1998). } \\
\text { The participants' ages may also have been related to the high proportion of two-parent } \\
\text { families in terms of the social acceptability of divorce at this age. Behaviour may be } \\
\text { influenced by the number of other people who are behaving similarly, making it less } \\
\text { acceptable to divorce when most other couples in that age-group are still together } \\
\text { (Lester, 1996). }\end{array}$ \\
\hline $\begin{array}{l}\text { Age of } \\
\text { dependants }\end{array}$ & $\begin{array}{l}\text { The majority of the participants were either expecting a child or had very young } \\
\text { infants. }\end{array}$ \\
\hline $\begin{array}{l}\text { Number of } \\
\text { dependants }\end{array}$ & $\begin{array}{l}\text { The majority }(59 \%) \text { of the participants had only one child, } 32 \% \text { of the participants had } \\
\text { two children, } 6 \% \text { had three and } 3 \% \text { had four children. This may be typical of more } \\
\text { affluent, developed areas where the current trend is for families to have fewer children } \\
\text { (Lester, 1996). }\end{array}$ \\
\hline $\begin{array}{l}\text { Level of } \\
\text { education }\end{array}$ & $\begin{array}{l}\text { The participants varied in their level of education from diplomas to doctorates and the } \\
\text { majority }(58 \%) \text { of participants had bachelor's degrees. Only } 7 \% \text { of the participants } \\
\text { had no tertiary education, indicating that participants in this study were well educated. }\end{array}$ \\
\hline Income & $\begin{array}{l}\text { The participants are mostly from the upper-middle income group. This may be } \\
\text { because the targeted geographical area is a developed area. It has been found that } \\
\text { external resources act as protective factors which help potentially at-risk children } \\
\text { from developing problems (Werner, 2000). }\end{array}$ \\
\hline
\end{tabular}


Table III A description of the participants in the focus group discussions $(n=11)$

\begin{tabular}{|c|c|c|}
\hline Aspect described & $\begin{array}{c}\text { Focus group one } \\
(X 1, n=5)\end{array}$ & $\begin{array}{l}\text { Focus group two } \\
(\mathrm{X} 2, \mathrm{n}=6)\end{array}$ \\
\hline Ages & $21 ; 29 ; 30 ; 32 ; 36$ & $19 ; 28 ; 30 ; 31 ; 33 ; 37$ \\
\hline Gender & all female & all female \\
\hline Family structures & $\begin{array}{l}\text { all nuclear family units with both } \\
\text { biological parents present in the home }\end{array}$ & $\begin{array}{l}\text { all nuclear family units with both } \\
\text { biological parents present in the home }\end{array}$ \\
\hline $\begin{array}{l}\text { Age of youngest } \\
\text { child in months }\end{array}$ & $1 ; 1 ; 3 ; 8 ; 16$ & $1 ; 1 ; 1 ; 4 ; 7 ; 11$ \\
\hline $\begin{array}{l}\text { Number of } \\
\text { children }\end{array}$ & $\begin{array}{l}\text { four of the participants had one child } \\
\text { and one participant had two children }\end{array}$ & $\begin{array}{l}\text { four of the participants had one child } \\
\text { and two participants had two children }\end{array}$ \\
\hline Level of education & $\begin{array}{l}\text { two participants had Masters degrees } \\
\text { and three participants had Bachelors } \\
\text { degrees }\end{array}$ & $\begin{array}{l}\text { one participant had a Masters degree, } \\
\text { four participants had Bachelors } \\
\text { degrees and one participant had a } \\
\text { Diploma }\end{array}$ \\
\hline $\begin{array}{l}\text { Annual family } \\
\text { income }\end{array}$ & $\begin{array}{l}\text { three participants had an annual family } \\
\text { income of between R } 100000 \text { and R } 215 \\
000 \text { (approx \$US } 15000 \text { and \$US } \\
32500 \text { ) while two participants had an } \\
\text { annual family income of above R215 } \\
000 \text { (approx \$US 32500) }\end{array}$ & $\begin{array}{l}\text { three participants had an annual family } \\
\text { income of between R } 100000 \& \text { R } 215 \\
000 \text { (approx \$US } 15000 \& \text { \&S } 32500 \text { ) } \\
\text { while three participants had an annual } \\
\text { family income of above R215 } 000 \\
\text { (approx \$US 32500) }\end{array}$ \\
\hline
\end{tabular}

Table IV: Professional participants who completed the survey $(n=84)$

\begin{tabular}{|c|c|}
\hline Criteria & Description \\
\hline Age & $\begin{array}{l}\text { Professional participants ranged in ages from } 24 \text { to } 68 \text {, and fell within the age groups } \\
\text { that are described as early and middle adulthood (Louw et al., 1998). This implies that } \\
\text { the wide range of opinions that were obtained reflect the viewpoints of professionals } \\
\text { from a range of ages. }\end{array}$ \\
\hline $\begin{array}{l}\text { Male versus } \\
\text { Female }\end{array}$ & $\begin{array}{l}\text { All of the professional participants were female. Since all professionals who qualified } \\
\text { to participate (according to the selection criteria) were asked to fill in a questionnaire } \\
\text { this is a reflection of the professionals who work in the relevant professions, within } \\
\text { the demarcated geographical area. It was therefore not possible to include male } \\
\text { professionals as there were none available. Research has indicated that certain jobs } \\
\text { within certain communities are typically dominated by a specific gender (Louw et al., } \\
\text { 1998). This is true for jobs in industries such as mining (Louw et al., 1998). It appears } \\
\text { also to be true for the professions and community that are included in this study. It is } \\
\text { unfortunate that no male professionals were available for inclusion as this infers a } \\
\text { gender bias in the results. The results may therefore not only reflect the needs and } \\
\text { preferences of professionals in the field but may also reflect preferences that are } \\
\text { characteristic to females. }\end{array}$ \\
\hline $\begin{array}{l}\text { Level of } \\
\text { education }\end{array}$ & $\begin{array}{l}49 \% \text { had bachelor's degrees, } 25 \% \text { had master's degrees, } 19 \% \text { had diplomas and } 7 \% \\
\text { had doctorate degrees. }\end{array}$ \\
\hline $\begin{array}{l}\text { Years of } \\
\text { professional } \\
\text { experience }\end{array}$ & $\begin{array}{l}\text { Professionals ranged in their experience from } 1 \text { to } 2 \text { years }(12 \%) \text { to } 30 \text { years } \\
\text { experience or more }(11 \%) \text {. Data therefore reflects the views and opinions of the } \\
\text { young, upcoming, recently graduated professionals as well as older, more mature and } \\
\text { more experienced professionals. Furthermore, trends in the prevention of } \\
\text { communication disorders and the provision of services to families have changed } \\
\text { constantly over the course of the last couple of decades (Gerber, 1990; ASHA, 1991; } \\
\text { Banigan, 1998; Rossetti, 2001). Opinions provided in the questionnaires therefore will } \\
\text { reflect both traditional and recent approaches to the prevention of communication } \\
\text { disorders. }\end{array}$ \\
\hline $\begin{array}{l}\text { Experience } \\
\text { with different } \\
\text { population } \\
\text { groups }\end{array}$ & $\begin{array}{l}\text { The majority of professional participants worked with parents of pre-schoolers }(90 \%) \text {, } \\
\text { pre-schoolers themselves }(83 \%) \text { or parents of infants }(64 \%) \text {. As the majority of the } \\
\text { professionals worked mostly with parents, and were responding to parental concerns } \\
\text { on a regular basis, they were ideally equipped for the task of determining the type of } \\
\text { information that should be made available to parents. }\end{array}$ \\
\hline
\end{tabular}


FIGURES TO BE INSERTED

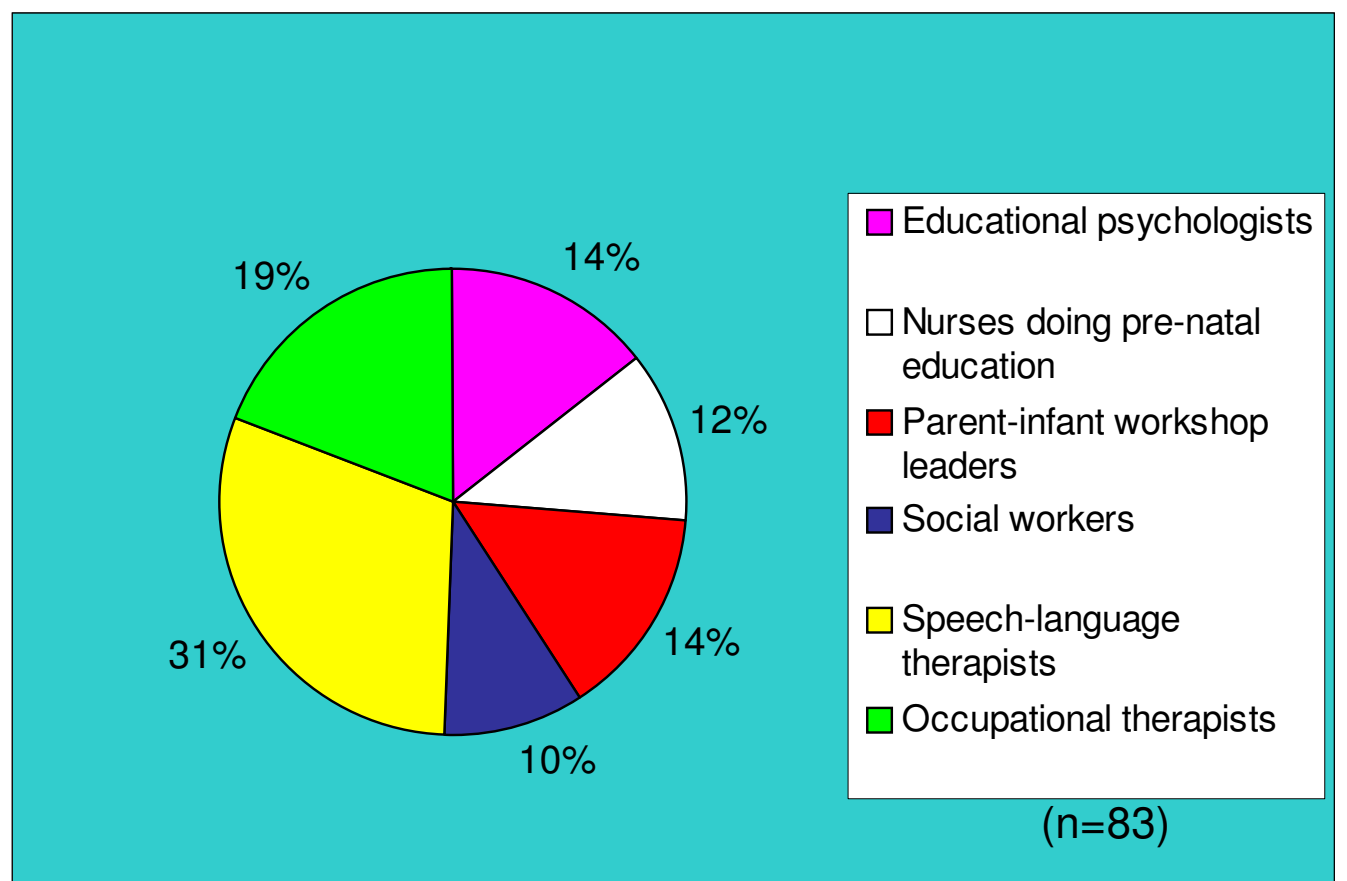

Figure 1 Professions of the professional participants

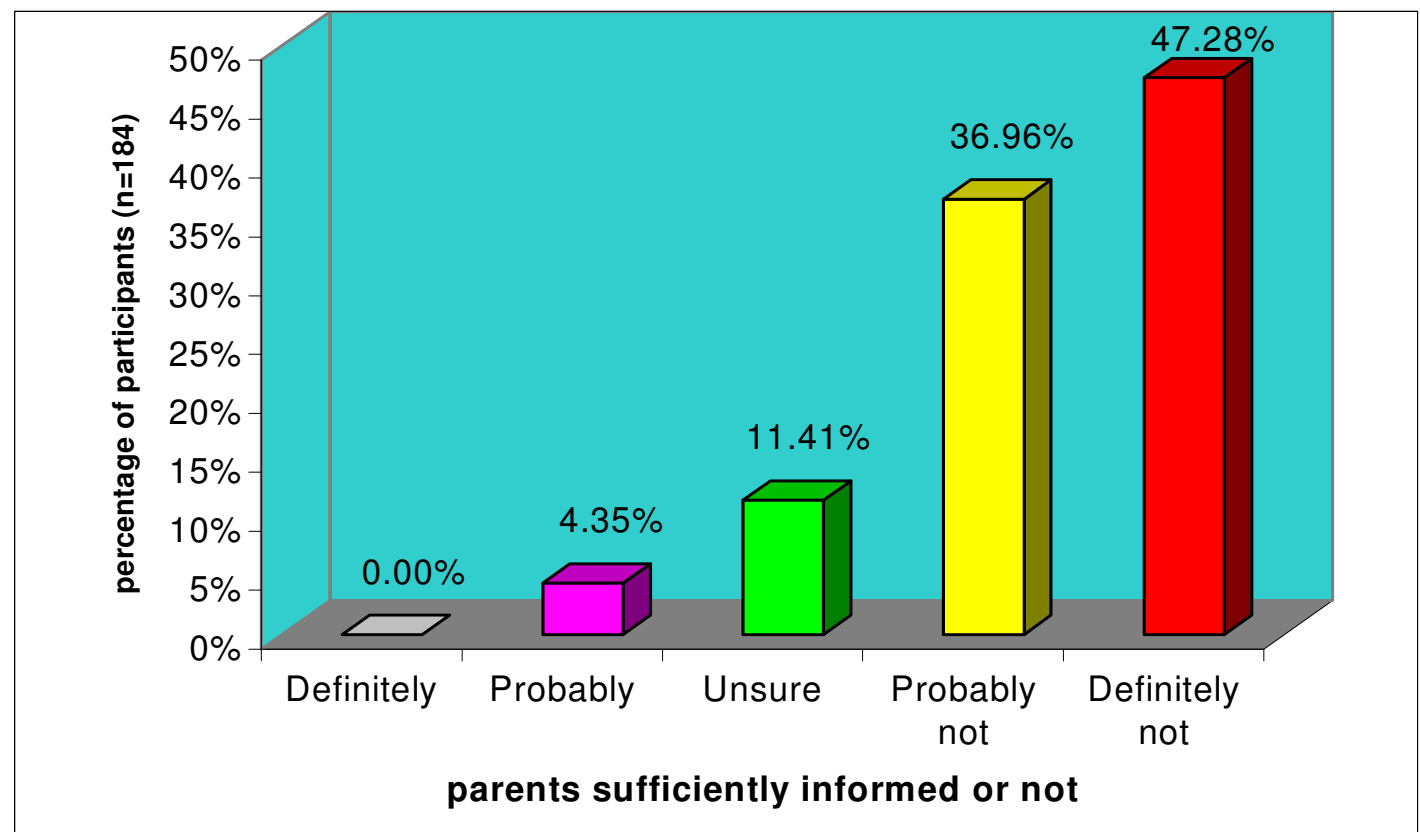

Figure 2 Parent participants' perceptions of their knowledge on infant communication development 


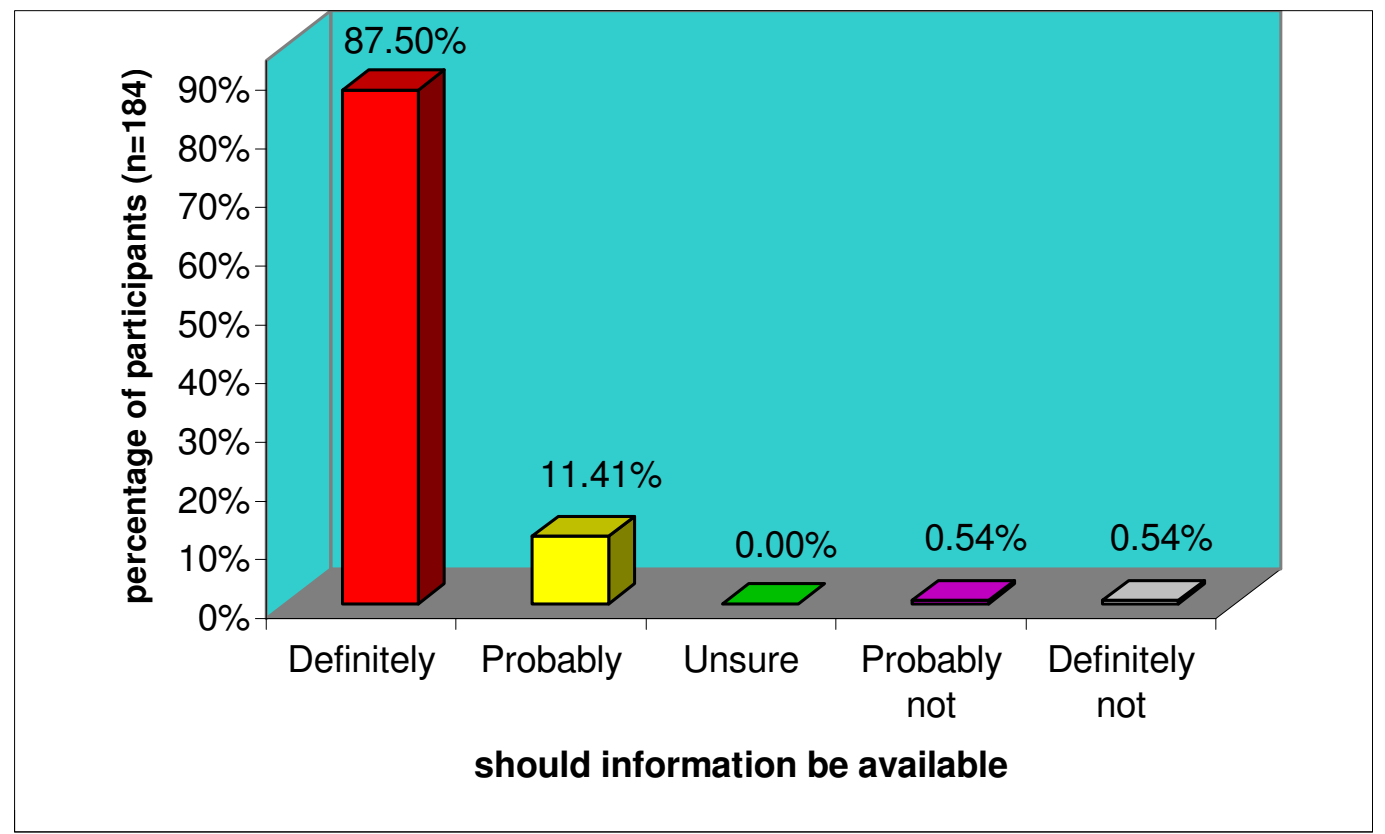

Figure 3 Parent participants' perceptions regarding the availability of information

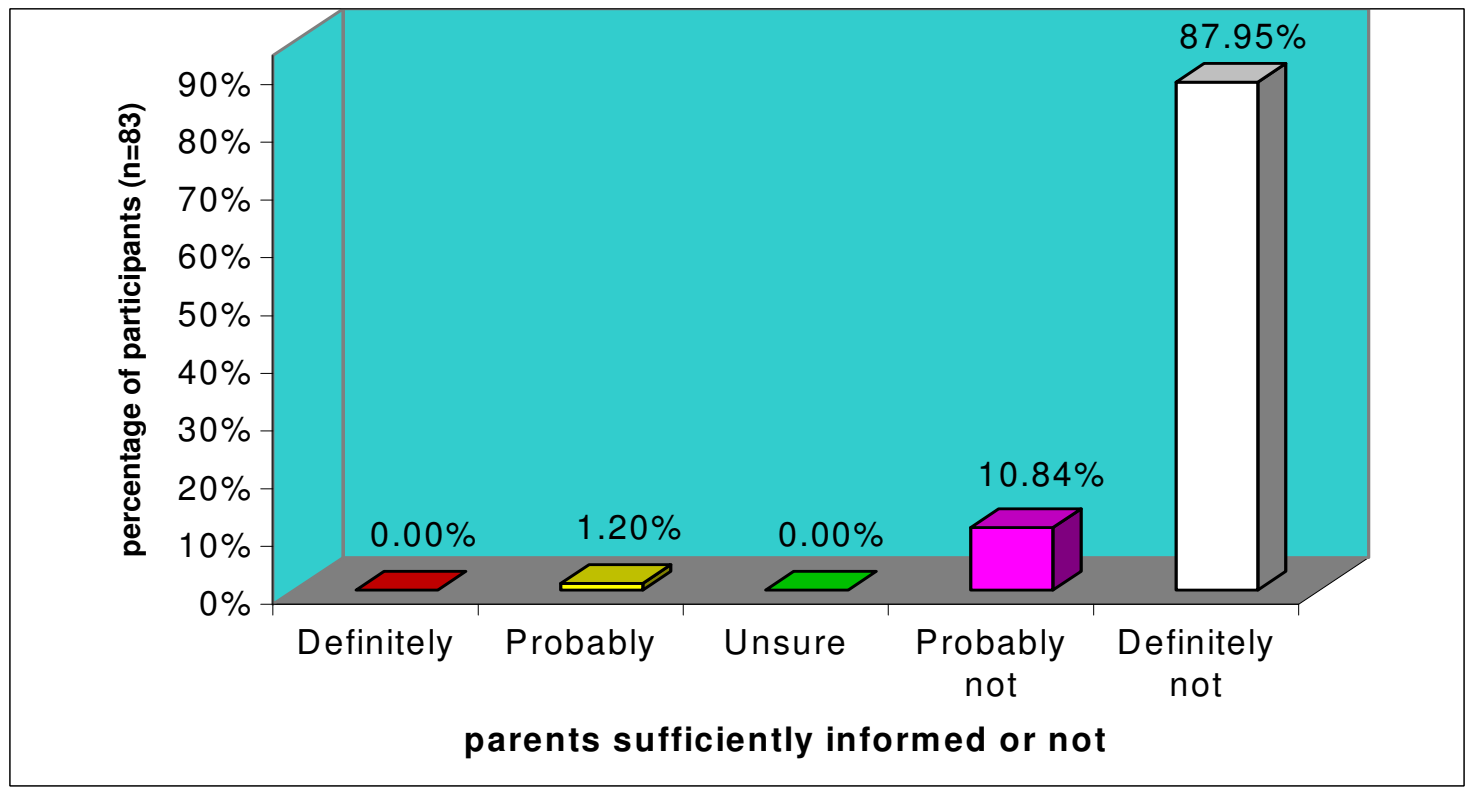

Figure 4 Professionals' perceptions of parental knowledge 


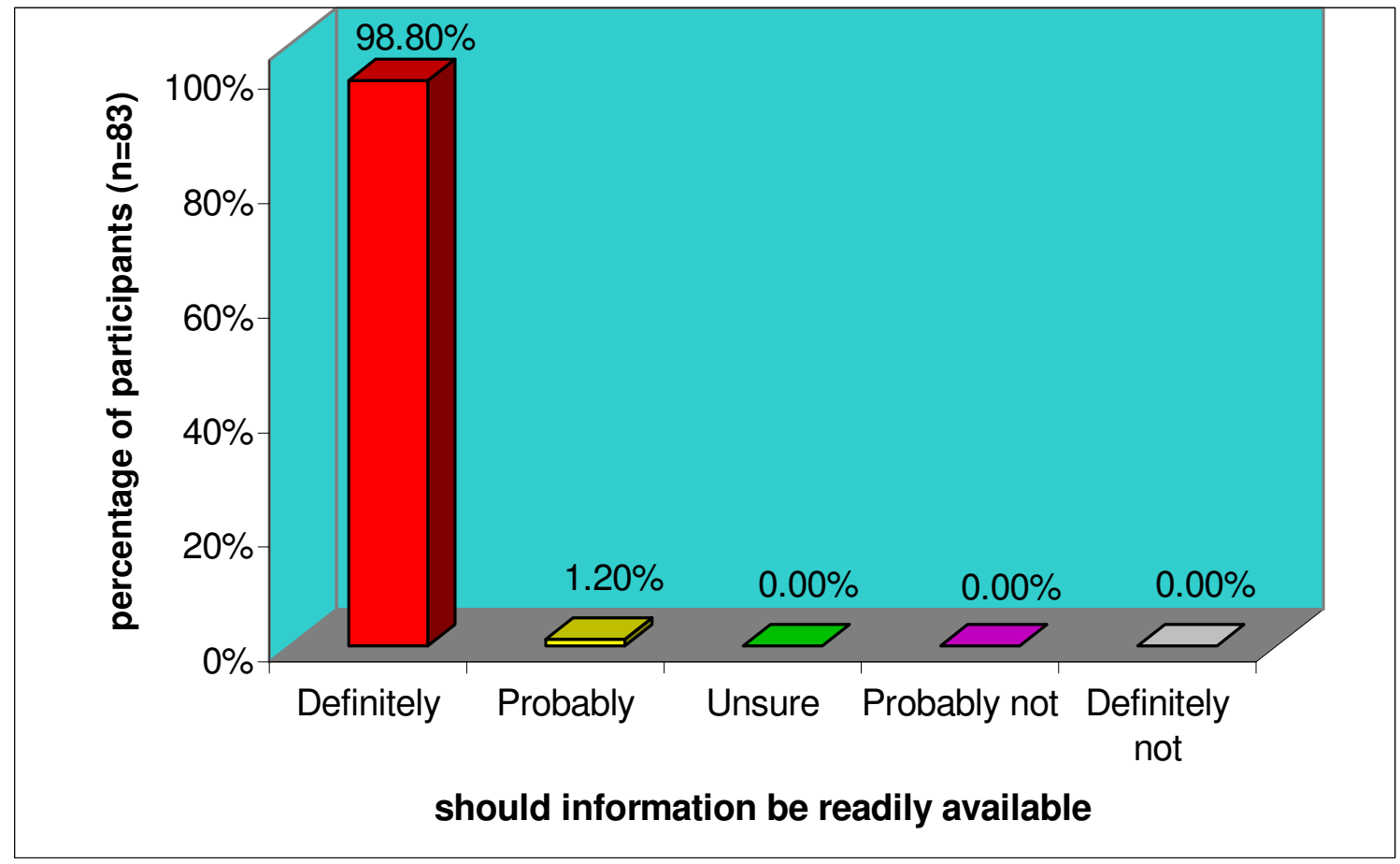

Figure 5 Professionals' opinions regarding the availability of information for parents

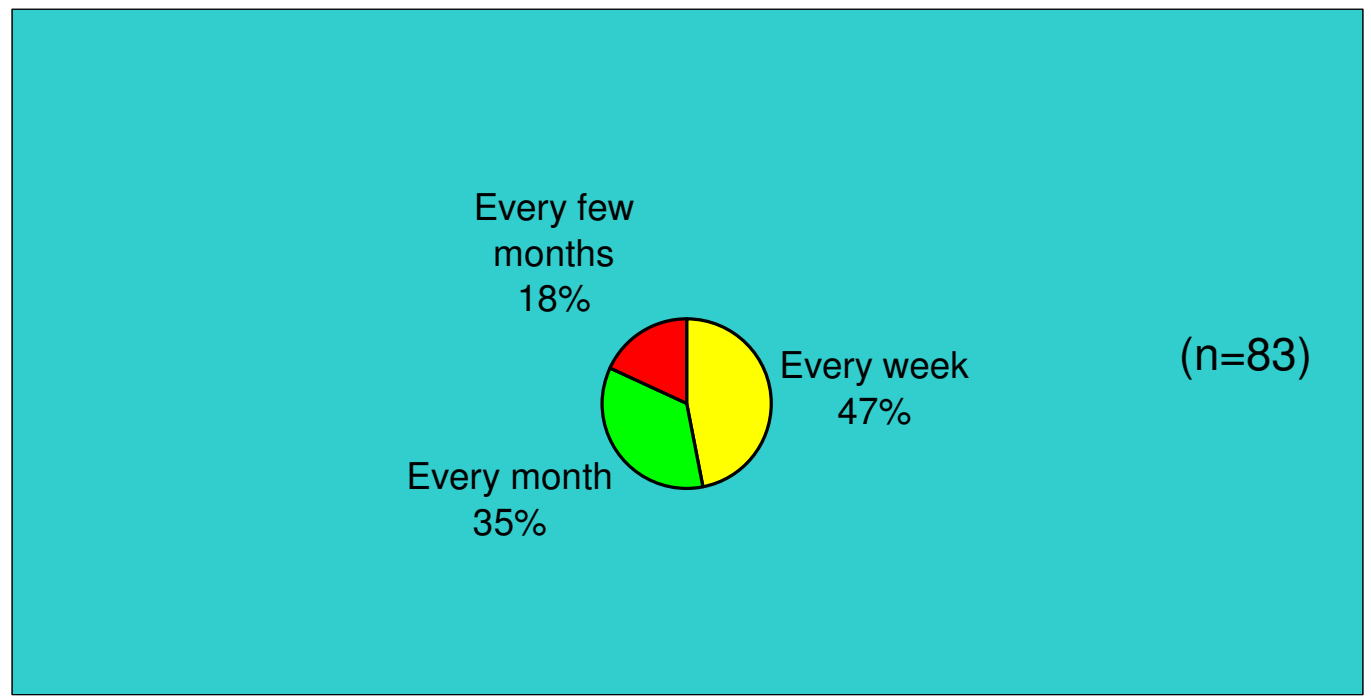

Figure 6 Perceptions of frequency with which professionals provide information 


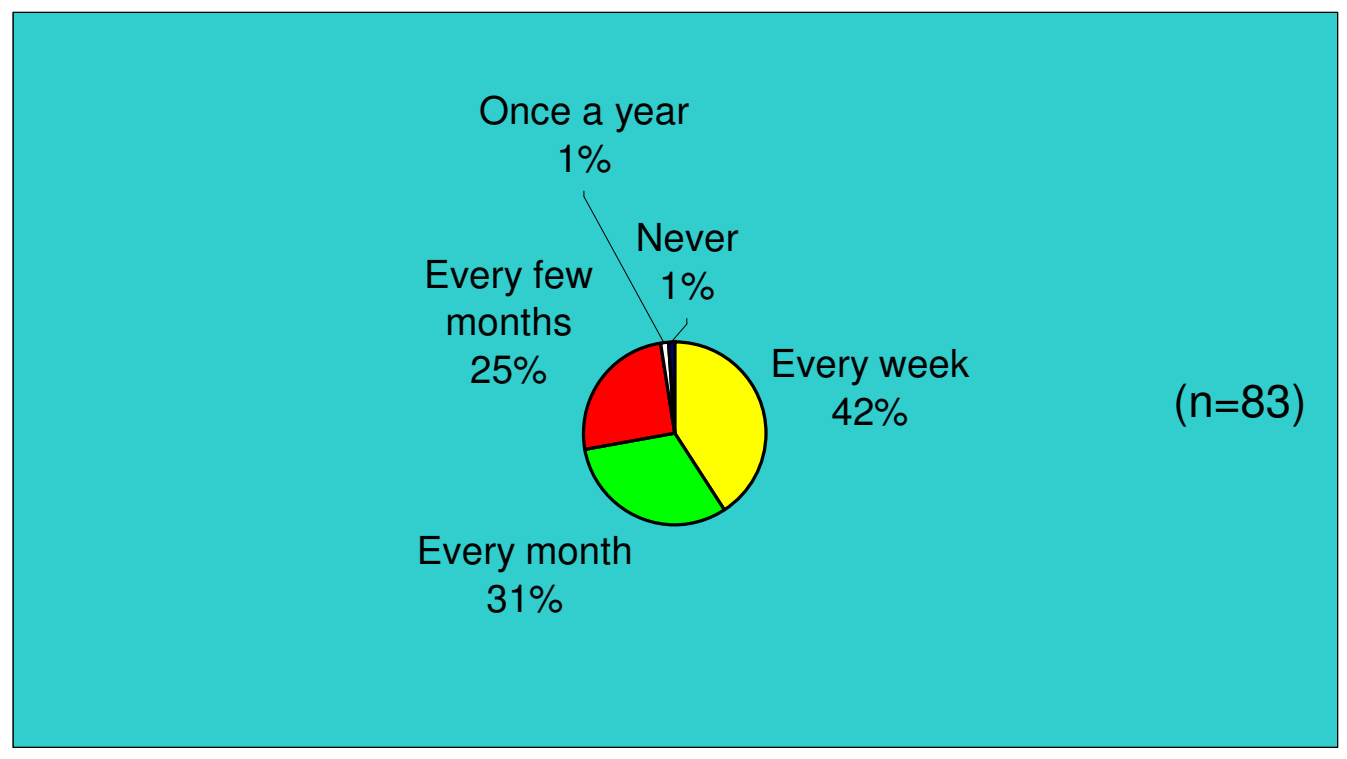

Figure 7 Perceptions of frequency with which parents request information 